\title{
A RESEARCH-BASED MANTRA FOR COMPASSIONATE CARING
}

Dr Louise Terry PhD LLB(Hons) FIBMS, Reader in Law and Ethics, School of Health and Social Care, London South Bank University, London, U.K.

Tel: 020 78158404, Email: terrylm@1sbu.ac.uk

Dr Roger Newham, DMedEth RN, Senior Lecturer, School of Nursing, Institute of Clinical Sciences, University of Birmingham, Edgbaston, U.K

Sinéad Hahessy MA (Soc Sc) BA (Hons) RGN, Lecturer, National University of Ireland, Galway, Republic of Ireland

Siobhan Atherley RN, Senior Lecturer, School of Public Health, Midwifery and Social Work, Canterbury Christ Church University, Medway, Kent, UK.

Dr Yolanda Babenko-Mould PhD MScN BScN RN, Associate Professor, Arthur Labatt Family School of Nursing, University of Western Ontario, London, Canada

Dr Marilyn Evans PhD MN BScN RN, Associate Professor, Arthur Labatt Family School of Nursing, University of Western Ontario, London, Canada

Karen Ferguson MHSc BHSc RN, Lecturer, Arthur Labatt Family School of Nursing, University of Western Ontario, London, Canada 
Graham Carr MRes MSc RN, Senior Lecturer, School of Health and Social Care, London South Bank University, London, U.K.

Dr SH Cedar PhD BSc, Associate Professor, School of Health and Social Care, London South Bank University, London, U.K.

This research did not receive any specific grant from funding agencies in the public, commercial or not-for-profit sectors.

Word count: 4969 words 


\title{
A research-based mantra for compassionate caring
}

\author{
Abstract \\ Background: The United Kingdom introduced the Six C's strategy to help address \\ deficits in approaching nursing care in a compassionate and caring manner. \\ Objective: To identify the book, article, poem, film or play that most influenced nurse \\ educators' understanding of care and compassion and to articulate a clearer \\ understanding of compassionate caring. \\ Design: A qualitative study applying discourse analysis to respondents' questionnaires \\ and their nominated narrative. \\ Settings and Participants: 41 nurse educators working in 5 universities in the UK $(n=3)$, \\ Republic of Ireland and Canada participated. 39 items (10 books, 2 journal articles, 10 \\ poems, 15 films and 2 plays) were nominated. \\ Findings: The desire to understand others and how to care compassionately characterised \\ choices. Three main themes emerged. Abandonment of, and failure to see, the suffering \\ person was evident in 25 narratives. Connecting with others was shown in 25 narratives \\ as being able to truly seeing the other person. Comforting others was supported by 37 \\ narratives with examples of kindness and compassion. \\ Conclusion: Published narratives are valuable in developing compassionate responses. \\ An annotated list is provided with suggestions for educational uses to help develop \\ compassionate caring in student nurses. Compassionate, caring nurses recognise that \\ patients need them to: "See who I am; Be present with me; Do not abandon me."
}




\section{$\underline{\text { INTRODUCTION }}$}

Nursing is a caring profession yet in the UK, people have suffered as a consequence of uncaring nurses (Care Quality Commission, 2011; Francis, 2013). In response, the 6 C's strategy was launched (Commissioning Board Chief Nursing Officer, 2012). The 6 C's are: Care, Compassion, Competence, Communication, Courage and Commitment. Attempts to characterise key nursing values are not novel; a Canadian nursing theorist, Sister Simone Roach, identified her five C's of Caring as: Compassion, Competence, Confidence, Conscience, Commitment in 1987 adding a sixth, Comportment, in 1992. Roach (2002, p.66) argues that when nurses base their caring in practice upon these, patients receive the "profound and virtuous care" that exemplifies good professional nursing. Both conceptualisations indicate that compassion is an integral component of being a 'caring' nurse yet it is unclear how nurses, or the educators shaping their practice, understand the nature of 'caring' and 'compassion'. Notwithstanding this, as nurse educators from the UK, Republic of Ireland and Canada, we believe that these can be fostered and developed. We each have had our understanding of compassion and caring influenced by narratives in various forms so the study reported here set out to identify, analyse and share published narratives which can be used by others to develop care and compassion in nursing students.

\section{LITERATURE}

Research often conflates "terms such as caring, empathy, sympathy, compassionate care, and compassion interchangeably, implying that these words are synonymous" (Schantz, 2007, p.49). "Caring" is reduced by some nursing theorists to activities such as feeding, clothing, providing medicine, helping others develop or sustain their basic abilities, or 
alleviate their pain (Schantz, 2007). Thus, caring is changed into a practice not a moral orientation; "carers" have not necessarily been recruited for their caring qualities or had these consciously developed (Engster, 2005).

Other nursing theorists remain true to the belief that a primary characteristic of nurses is that they "need to help others" (Sumner, 2008, p.239). Sumner's theory of the moral construct of caring in nursing as communicative action conceptualises caring in nursing as bi-directional communication where both patient and nurse have "physical, social, spiritual and emotional needs" even if those of the nurse are less overtly acknowledged (Sumner, 2008, p.236). Consequently, even the most caring nurse may suffer compassion fatigue (Sabo, 2006), moral distress (Epstein and Hamric, 2009) or burnout as a consequence of the emotional labour of nursing (Smith, 2012; Hochschild, 1983). Research often concentrates on recognising compassion fatigue, supporting the professional who is suffering from its effects (Showalter, 2010) and preventing burnout (Inbar and Ganor, 2003). The identified costs, as articulated by Showalter (2010) mostly focus on the employer and employee (staff turnover, loss of self-worth, diminished productivity and poor morale) without recognising that caring work necessarily involves personal interaction between the professional and the care recipient. As Sumner (2008, p.240) identifies, nurses should be "providers of comfort" but withdrawal of the caring component from the care interaction (characteristic of a compassion-fatigued professional) is an unacknowledged cost. As long as activities of care are performed, the way care is provided may seem unimportant. As Kennedy (2001, p.265) noted, healthcare professionals are taught what is best but "expected to practice in circumstances in which 
'getting' by is prized as success". These are the conditions in which failures of care (and caring) occur.

In response, some educators are seeking ways to develop caring qualities. Griffiths et al's (2012) focus group-based study of 52 patients and carers revealed themes that the researchers related to a "caring professional attitude". In reality, their supporting evidence focused on professionalism (including technical competence, non-judgmental attitudes, empathy and communication skills) with little evidence of depth of caring. They suggest using role modeling and blended learning such as blogs to accompany lectures; this seems a rather "academic" response that may fail to reach practitioners deeply.

This is where the humanities have a role by taking people beyond the confines of their professional field. The arts enable us to access emotional responses that we suppress for fear of looking unprofessional, thereby risking the loss of ability to connect and empathize with others (Gaut, 2007). Arts-based pedagogy is increasingly popular in healthcare education with a diversity of methods being utilised (McLean, 2014). McKie et al (2008) employ art, film, literature and photography. Roberts (2010) favours poetry to specifically engage the construct of empathy in mental health nursing students. Author3 (2016) uses published poetry to engage nursing students in reflective practice. Books, articles, poems, plays and films all contain narratives which engage and influence. Narrative can be seen as the design of a building, its architecture, comprising multiple stories (or rooms) that relate to one another (Author1, 2013). Thus, by asking nurse 
educators to identify the single, most influential narrative (however conveyed) and to explain why it influenced their understanding of compassion and caring and how they used it to educate others, we aimed to develop a list of resources and suggestions for educators and, by analysing the narratives, we aimed to be able to articulate a clearer understanding of compassionate caring.

\section{$\underline{\text { METHODS }}$}

The theoretical framework of this study is underpinned by Sumner's (2008) thesis that nursing is a moral, bi-directional activity between the nurse and the patient/client which is characterised by caring and compassion. Sumner (2008, p.260) provides a diagrammatic representation and concludes that "in the ideal communicative relationship both nurse and patient are equal participants." The nurse brings their personal and professional selves to the encounter and the patient brings their personal and illness self. Together, Sumner argues, they "are engaged in discourse with an outcome of <physis> or validation" (ibid). Once trust is present, the nurse can help the patient and the patient can accept help.

The methodology used is discourse analysis (DA). This was employed rather than a simpler narrative analysis since DA allows the analysis of 'texts' (understood as not just the written word: Gee 2014), for their wider social significance thereby making explicit what is implicit with the multifaceted nature of situated relationships (Schiffrin 1997, Cameron 2001). One such relationship is that of the nurse and patient/client, a somewhat contested relationship for reasons such as power and professional ideologies or 
professional identities affecting how caring and compassion are understood (Crowe 1988; Smith 2006).

A questionnaire was emailed to potential participants (see Box 1). Completed questionnaires were analysed using DA. A fuller explanation of the method and discourse analysis tool developed for this project has been published (Author1 and Author2 2016) as a research methods paper so a shorter overview is provided here. Gee's (2014) discourse analysis 'toolkit' was influential but Gee fails to discuss how to combine his tools or address concerns of rigour (an issue often lacking consideration in DA research: Nixon and Power, 2006). DA involves context and interpretation (White 2004) and sole researchers may miss important points. Antaki et al, (2003) identify common errors in DA research: under-analysis, taking sides, over-quotation or isolated quotation, circular identification of discourses and mental constructs, false survey and analysis that consists in simply spotting features. Our method and tool was designed to maximise rigour. The tool was designed by the two lead researchers and piloted within the research team. The tool aimed to identify (1) identities, relationships and politics (2) constructs (3) words (what they conveyed and how they were used) (4) key topics and contextual meanings (5) the implications of audio or visual images (6) primary and secondary discourses and (7) impact upon the nominating educator and usage of the narrative to educate others.

Exploring identities meant reading or watching to understand each person's primary narrative about themselves; their secondary narrative; what 'identity' was imposed on them and how people interacted. This was particularly important in light of the 
underpinning theoretical framework. When identifying constructs, topics and contexts, we had to be open to omissions, such as the absence of compassion so this meant seeking to understand beyond words. Film proved easier in some respects as there are words, expressions or events happening behind the characters on main screen, or mood-affecting music. When exploring words, we needed to have the nominated text (or film narrative) and a sense of how the educator interpreted it and why they nominated it. For example, the nominator of Gibran's The Prophet explained that it "really just brought together the philosophy and faith I had been taught by my parents and grandparents who were the primary influence in my development of compassion and the ability to care and love". We also needed to elicit what the overall discourse regarding care and compassion was and whether there were any omissions or contradictory discourses.

Eight research team members nominated their own most influential narrative and then the team analysed these as a pilot stage with each narrative being examined by two, three or four members. It was determined that a minimum of two researchers should analyse each narrative in order to avoid missing aspects. The analyses revealed contrasts, for example, the film Defiance shows all aspects of the human condition and how actions can be constructed in different ways depending on the circumstances. The educator suggested it is "great for leadership" but one researcher's DA sheet (showing emotion in the word “slaughtered") reported:

“At times, all the people are weak, flawed, quarrelsome, often because of deprivation ... they are not always strong, compassionate, just or caring but ultimately, and collectively, they manage to be sufficiently caring and 
compassionate towards each other for so many people to join the group and for the group to be open to newcomers such that over 1200 people survived the war who probably would have been slaughtered by the Germans."

The completed analyses were consolidated into a compendium circulated to the team for them to analyse through their in-depth engagement with the created text. This allowed team members to identify what understandings of compassion emerged for them and what they felt were the major themes and key messages that were important to share with other nurses. The analyses of the compendium were synthesised and subjected to a final level of DA (the abduction stage) by the two lead researchers. In addition, the lead researcher subjected the compendium and the analyses of the compendium to content analysis. This enabled all the varying expressions of compassion (words and behaviours), characteristics, themes and discourses to be listed against the nominated items in which they were present. For example, trust (a key component of Sumner's model) was present in only six of the nominated items. This method meets the required four aspects of validity for DA as identified by Gee and Green (1998) which are: convergence, agreement, coverage and linguistic detail.

\section{Ethical Approval}

Ethical approval was obtained from the five universities involved. Primary ethical approval was received from the UK university research ethics committee at which the principal investigator is based. Following this, ethical approval was obtained from the others. Obtaining these was time-consuming but there were no concerns since potential participants were autonomous professionals. None of researchers had managerial roles that might raise concerns of power imbalances. Completion of the questionnaires (which 
were emailed to potential participants along with an information sheet regarding the study) was deemed consent. In Canada, following an ethics amendment, three questionnaires were administered in audio-recorded face-to-face interviews then transcribed.

Sample:

Participants were registered health and social care professionals employed within one of five universities with nurse education as part of their roles. In total, 41 completed questionnaires were received representing 38 nurses, 1 doctor, 1 biomedical scientist and 1 occupational therapist.

\section{$\underline{\text { FINDINGS }}$}

In total, 39 separate texts were nominated and analysed (Table 1) comprising 10 books (one contained a nominated poem analysed separately from the book), 2 journal articles, 10 poems, 15 films and 2 plays. This produced 366 pages of analysis analysed as a text in its own right by five members of the team (covering all three countries). This provided holistic analysis and the potential impact of differing socio-political-professional perspectives that might occur within the UK, Irish and Canadian nursing and healthcare systems to be accommodated. The strongest themes were abandonment, connecting with others and providing comfort.

\footnotetext{
Abandonment

There were examples of tenderness or gentleness in 35 of the narratives but the majority were predominantly negative in that caring and compassion were portrayed through their
} 
absence (by evoking compassionate responses in participants). Abandonment of the suffering person was evident in 24 narratives (Bauby's The Diving Bell and the Butterfly, nominated three times is a clear example) which suggests that non-abandonment is a key component of being caring and compassionate since invisibilisation and abandonment were the most common examples of the absence of compassion (see Table 2).

Narratives that included nursing care showed how variable people's experiences were. Sue Baier, paralysed with Guillain-Barré, wrote,

"I tried to move my lips, just a little twitch of my mouth to indicate no. Nothing moved. Crushing disappointment. But it didn't matter to Craig. Methodically he checked my blood pressure and pulse, my vital signs. Craig, I thought, you certainly failed your course on bedside manner. Without a word, he rolled me slowly, firmly, to my left side, again propping pillows behind my back. He didn't notice the wetness of my right cheek, or the pool that must have accumulated on the bed, or the new gush that was now coursing down my left cheek. Silently he turned off my light and disappeared...I am constantly alone. The nurses are close by in that nursing station, but they are busy talking, laughing, doing other things. I know they have monitors on me, but how can they be so indifferent and cold?"

Havi Cavel (in Illness) feared losing her identity and only being seen as an oxygendependent person "memorable for her deficiency." In reality, the "sullen and unfriendly" nurse who stood by "stony but for her slight impatience" when Carel is 
crying and struggling to breathe is memorable for her deficiency to express compassion.

Cavel questions, "what sort of training has made her [the nurse] able to stand there, saying nothing, offering no words of comfort or distraction? Does she do this every day, to all her patients? Does she feel nothing but annoyance towards me?...Does she think of me as a person?" (p.39).

Connecting with others

The ability to connect with others was present in fewer than half the narratives $(n=16)$. The strongest theme, present in 25 narratives, was that in order to be caring and compassionate, it is necessary to be able to see the other person as they really are: a suffering fellow human being. It is through seeing, that one can start to connect. In As you journey (Perry, 1998), caring, and probably compassion too, means being open to seeing the beauty around you "for it is all around you in forms not easily recognisable" even though many of the people that healthcare professionals care for are not physically beautiful people and illness, disease and old age can be merciless. Perry's book is based on her doctoral research observing exemplary nurses and the nominated poem summarises everything that characterises excellent nursing care.

In the film Invictus, Nelson Mandela heals the wounds of apartheid in South Africa because "To him, no one is invisible". This ability clearly impressed Hendricks, the (white) head of Special Branch who had guarded the former (white) president FW 
DeKlerk when he tells François Pienaar, captain of the (white) Springboks rugby team, what the new president is like. Mandela unites South Africa around the Springboks and the 1995 Rugby World Cup.

One educator's explanation for her nominated narrative in words suggest that expressing compassion is grounded on an ability to connect with others and this derives from being interested in the other person.

"Until we become more curious about those we come across, shift from a reductionist perspective and recognize that knowing someone and understanding their world and experience can allow us to be empathic, compassionate and caring, nothing will change in a reductionist account of caring or health etc" (UK nurse).

Some were inspired in their own lives by their chosen narratives and explained how they role modeled these qualities of seeing and connecting for their students. For example, one Canadian nurse reported finding the first and second stanzas of Perry's 1998 poem most powerful:

"Touch others, physically, emotionally, intellectually, and spiritually Learn to use silence, it provides a powerful means of communication"

The lack of narratives showing trust is particularly concerning. In Apollo 13, the lack of trust in Swigert who was a last-minute substitution to the crew is evident. Without trust, they will die but eventually trust builds, Houston accepts offers of help from around the 
world, and the crew are brought safely back to earth. This film reminds us of how we all seemed connected for those few, long days.

Comforting others

Practical responses to suffering were evident in 24 narratives. Some narratives $(n=15)$ had examples where the caregiver gave more of themselves than their professional role demanded and caring carried an emotional toll in 8 narratives but 7 other narratives showed a balanced approach to the care of the individual patient. Table 3 lists the participant educators' understandings of how to practically express caring and compassion as evidenced in the narratives and their questionnaire responses.

Reflecting Sumner's (2008) recognition that providing comfort is a central aspect of a nurse's role whether by words or behaviours, the value of a smile was evident in several texts. In the book (and film) The Little Princess (Frances Hodgson Burnett, 1905), people move into the house next door and one night Sara spots an Indian servant. He looks "sorrowful and homesick" so she smiles at him as "she had learned to know how comforting a smile, even from a stranger, may be”. In the film, The English Patient, the horribly disfigured, burnt patient asks the nurse for some water; as she provides it, she smiles and makes eye contact. There was no revulsion at his appearance, merely kindness and compassion. She is present with him.

Providing comfort was also evident in the film Wit. It was 4am (the darkest hour of all), Vivien, who is dying of stage 4 ovarian cancer, is craving human contact so clamps one 
of her tubes to make the alarm go off. The nurse comes and listens. Vivien starts crying; she is scared and no longer the self-assured, highly-respected academic she had been. The nurse strokes her arm, holds her hand and reassures her. She gets a tissue, strokes her arm again and offers to fetch a popsicle. She brings two, so Vivien hands her one. The nurse sits beside her, relaxed, with feet tucked up, both of them sucking on popsicles. For a moment in time, they are connected as equals, sharing a treat like two children.

\section{$\underline{\text { DISCUSSION }}$}

The desire to understand others and understand how to care well, to be a caring and compassionate nurse seemed to characterise the educators' choices and responses to their nominated narrative. Many narratives had no link to nursing or healthcare but they all showed how a failure to connect with others leads to a sense of abandonment and isolation. Without connection, there can be no trust; without trust, there is no connection. Although some of the narratives were dated, there are still people today who feel abandoned by poor nursing care or indifferent nurses. The positive examples of caring and compassion were rendered more powerful by their contrast to the examples where these qualities were absent. It was also clear that even when the nominated item portrayed nurse-patient interactions, they might lack currency (The English Patient is set during World War Two) or authenticity as in Wit. A nurse who sat with her feet up sucking a popsicle with a patient would probably be seen as unprofessional but the equality of connection between nurse and patient, which allows the conveying of compassion and comfort to take place, is a very powerful message. Sumner (2008, p.201) 
explains, "In ideal communication the humanness of both nurse and patient, as human beings is revealed. They can openly and mutually respond to each other."

Nursing students need to develop their theory and practice. Experience over time helps with this (Benner, 1984) but the value of narratives such as those identified here is that they can help expose nursing students to a wider range of different situations than they have probably yet encountered. Some of the narratives demonstrate caring and compassion. Others hold the potential to trigger compassionate responses and potentially outrage at some of the injustices portrayed. Outrage is useful for developing emancipatory and socio-political knowing which Chinn and Kramer (2015) identify as necessary to develop nursing praxis. We believe that both types of narrative are valuable in helping nursing students develop the ability to engage with their patients and clients in a compassionate manner because they all hold the potential to "open their eyes". As Sumner (2008, p.255) observes "...both the nurse and the patient come to the interaction as complete human beings, with a past, and hopes for the future impacting on the present. They both think and they both feel which make both cognition and emotion essential components within their discourse". Nursing requires closeness but fear of knowing what to do or say can make student nurses withdraw from patients (Cooper and Barnett, 2009). Sumner (2008, p. 235) recognises this risk, "Because all socialization can only occur in communication this means that each [patient and nurse] is exposed which leaves them vulnerable". It can be particularly difficult for nursing students to develop understanding of the multiple faces of the patient-family-healthcare professional triad since this is often challenging for registered nurses (Hall, 2011). No one is "just" a nurse, or a patient, but 
the structure of healthcare delivery can make this an overpowering paradigm which compartmentalises healthcare practitioners and the recipients of care to as "Nurse", "Doctor", "patients", "clients", "service users" (the present, depersonalizing UK. terminology), "relatives". Consequently, students are at risk of developing their clinical practice within the confines of a contextual subjectivity (silo thinking) (Knight, 2011). This might be one of the reasons why nursing in the UK is facing criticism that its compassion is lacking.

The arts in all their forms, not just books, poems, articles, plays and films, can engender reflection, response and change. Worldwide, nurses increasingly embrace Schon's (1991) concept of the reflective practitioner (building on Dewey's (1933) seminal treatise). Reflecting upon real episodes of care can be challenging, particularly if the nurse or student feels that they may have failed the patient, because unconscious, protective mechanisms can intervene. Continued repression of emotional responses creates a risk of losing the ability to connect and empathize with others according to Gaut (2007). As educators aiming to humanise healthcare, it is important to help develop caring and compassionate attitudes and behaviours in the next generation of nurses as well as help those who have become jaded to rediscover their sense of themselves and their patients. The best educators act as guardians and ambassadors of professional values as well as enablers of student learning thereby leaving a legacy in the impact they have upon others (Macfarlane, 2012).

\section{LIMITATIONS}


Since the poem "Kate" is highly popular with many nurses worldwide, participants were asked not to nominate this the poem but it appeared under its variant names (Crabbit Old Woman and Look Closer Nurse). Originally, it had been planned that all members of the team to carry out the synthesising analysis of the compendium but workloads and illness prevented some from doing this. It is worth noting that we significantly underestimated the time involved in using DA as rigorously as designed. It is likely that participants were those to whom caring and compassion are important so some nuances may have been missed but recruiting from five universities in three different countries means that the potential impact of the geo-social context of nursing is reduced making findings more generalisable. A future study could seek to explore the most influential non-English narratives from international nurses for whom English is not their first language. This could help reveal wider cultural influences and understandings of compassion, for example, from Filipino or Spanish nurses working in other counties.

\section{CONCLUSIONS}

Humane healthcare requires reflective, reflexive, caring and compassionate nurses who can "see" their patients and clients as the real, authentic, valuable human beings they are (or should be) to themselves. The arts are invaluable in humanising healthcare education. The educators in this study believe that encouraging students to engage with wider narratives than simply health and social care ones opens their students' eyes and widens their understanding of their patient's world. As nurse educators, we believe this study has helped illuminate understandings and expressions of compassion and identified resources to help create the caring, compassionate nurses who make everyone they encounter, regardless of who or what they are, feel visible, valued and comforted. As Baier (1985, 
p116) observed "What a difference good nurses make." Compassionate, caring nurses recognise that patients need them to: "See who I am; Be present with me; Do not abandon me." These twelve words should become a mantra for all nurses.

\section{$\underline{\text { References }}$}

Antaki, C., Billig, M., Edwards, D., Potter,J. 2003. Discourse analysis means doing analysis: a critique of six analytic shortcomings. Discourse Analysis Online. 1, 1. http://www.shu.ac.uk/daol/previously/v1/n1/index.htm (Last accessed November, 19, 2015).

Author1, 2013 = Terry LM. Digital Stories in Teaching Ethics and Law to Health and Social Service Professionals. In: Cheryl McLean (Ed) Creative Arts in Humane Medicine, 2013, Toronto, Brush Education Inc13

Author1., Author 2, 2016 = Newham R, Terry L et al. Nursing as a moral profession: insights from nurses' elected narratives of care and compassion, Nursing Ethics, 2017 [Online First] doi/ pdf $/ 10.1177 / 0969733016687163$.

Author3, 2016 = Hahessy, S. 2016 Reflections on the use of poetry in nurse education: Speaking a credible language of care. Nurse Education in Practice (16) 140-143.

Benner, P. 1984. From novice to expert: excellence and power in clinical nursing practice. Addison-Wesley, Menio Park CA.

Bezzina, M., Burford, C. 2010. Leaders transforming learning and learners: an Australian innovation in leadership, learning and moral purpose. Advances in Educational Administration, 11, 265-283. 
Bottery, M. 2004. The Challenges of Educational Leadership: Values in a globalised age. Paul Chapman Publishing, London.

Cameron, D. 2001. Working with spoken discourse. Sage, London.

Care Quality Commission. 2011. Dignity and nutrition inspection programme: National overview. Available at:

http://www.cqc.org.uk/sites/default/files/media/documents/20111007_dignity_and_nutriti on_inspection_report_final_update.pdf (accessed 11 July 2012).

Chinn, R., Kramer, P. 2015. Knowledge Development in Nursing: theory and process, 9th ed. Mosby, St Louis.

Commissioning Board Chief Nursing Officer and DH Chief Nursing Adviser. 2012.

Compassion in Practice. Available at: http://www.commissioningboard.nhs.uk (accessed July 2013).

Cooper, J., Barnett, M. 2005. Aspects of caring for dying patients which cause anxiety to first year student nurses. International Journal of Palliative Care 11(8), 423-430.

Crowe, M. 1998. Discourse analysis: towards an understanding of its place in nursing. Journal of Advanced Nursing 51(1), 55-63. 
Dewey, J. 1916. Democracy and Education. Macmillan Inc., New York.

Engster, D. 2005. Rethinking care theory: the practice of caring and the obligation to care. Hypatia 20(3), 50-74.

Epstein, E.G., and Hamric, A.B. 2009 Moral distress, moral residue and the crescendo effect. Journal of Clinical Ethics 20(4), 330-42.

Francis, R., (Chair). 2013. Report of the Mid-Staffordshire NHS Foundation Trust Public Inquiry: Executive Summary. The Stationery Office, London. (ISBN: 9780102981476)

Gaut, B. 2007. Art, emotion and ethics. Oxford University Press, Oxford.

Gee, J. 2014. How to do discourse analysis: a tool kit. Routledge, Abingdon.

Gee, P., Green, J. 1998. Discourse analysis, learning and social practice: a methodological study. Review of Research and Education 23, 119-169.

Griffiths, J., Speed, S., Horne, M., Keeley, P. 2012. 'A caring professional attitude': what service users and carers seek in graduate nurses and the challenge for educators. Nurse Education Today 32 (2),121-127. 
Hall, T. 2011. Designing from their own social worlds: the digital story of three African American young women. English Teaching Practice and Critique 10(1), 7-20.

Hochschild, A. 1983. The managed heart: commercialization of human feeling. University of California Press, Berkeley CA.

Inbar, J., Ganor, M. 2003. Trauma and compassion fatigue: helping the helpers. Journal of Jewish Communal Service 4, 109-111.

Kennedy, I., (Chair) 2001. The Report of the Public Inquiry into children's heart surgery at Bristol Royal Infirmary 1984-1995. CM5207(I) Available from http://www.bristolinquiry.org.uk (accessed 11 July 2012)

Knight, S. 2011. Using narrative to examine positionality: powerful pedagogy in English education. English Teaching: Practice and Critique 10(2), 49-64.

McLean, C. (ed). Creative arts in humane medicine. Brush Education, Alberta, Canada. McKie, A., Adams, V., Glass, J.P., MacDuff, C. (2008) Windows and mirrors: reflections of a module team teaching the arts in nurse education. Nurse Education in Practice, 8, $156-164$.

Macfarlane, B. 2013. Intellectual leadership in higher education. Society for Research into Higher Education, Abingdon. 
Nixon, A., Power, C. 2006. Towards a framework for establishing rigour in a discourse analysis of midwifery professionalism. Nursing Inquiry 14(1) 71-79.

Roach, S. 1987. The human act of caring: a blueprint for the health professions, Canadian Hospital Association Press, Ottawa, Ontario.

Roach, S. 1992. The human act of caring: a blueprint for the health professions, revised ed. Canadian Hospital Association Press, Ottawa, Ontario.

Roach, S. 2002. Caring, the human mode of being: a blueprint for the health professions, $2^{\text {nd }}$ revised ed. Canadian Hospital Association Press, Ottawa, Ontario.

Roberts, M. (2010) Emotional intelligence, empathy and the educative power of poetry: a Deleuzo-Guattarian perspective. Journal of Psychiatric and Mental Health Nursing, 17, 236-241.

Sabo, B. 2006. Compassion fatigue and nursing work: can we accurately capture the consequences of caring work? International Journal of Nursing Practice 12(3), 136-142.

Schantz, M. 2007. Compassion: a concept analysis. Nursing Forum 42(2), 48-55. 
Schon, D. 1991. The Reflective Practioner: how professionals think in action. Avebury, New York.

Schiffrin, D. 1997. Theory and method in discourse analysis: what content for what unit? Language and Communication 17(2), 75-92

Showalter, S. 2010. Compassion fatigue? What is it? Why does it matter? Recognizing the symptoms, acknowledging the impact, developing the tools to prevent compassion fatigue, and strengthen the professional already suffering from the effects. American Journal of Hospice and Palliative Medicine 27(4), 239-242.

Smith, J. 2006. Critical discourse analysis for nursing research. Nursing Inquiry 14(1), $60-70$.

Smith. P. 2012. The emotional labour of nursing revisited, $2^{\text {nd }}$ ed. Palgrave MacMillan, Basingstoke.

Sumner, J. 2008. The moral construct of caring in nursing as communicative action: a theory for nursing practice. VDM Verlag, Saarbrucken, Germany.

White, R. 2004. Discourse analysis and social constructionism. Nurse Researcher 1(2) 716. 
Table 1: List of nominated narratives with overviews

\begin{tabular}{|c|c|}
\hline Books & Overview \\
\hline $\begin{array}{l}\text { Baier, S. and Zimmeth, M } \\
\text { (1985) Bed Number Ten, } \\
\text { Holt, Rinehart and } \\
\text { Winston, New York. }\end{array}$ & $\begin{array}{l}\text { The book was written by Sue Baier who developed a } \\
\text { severe form of Guillain-Barré in 1980. She was admitted } \\
\text { to Bed Number Ten in intensive care where she spent } \\
\text { several months ( } 9 \text { months in hospital in total). The book } \\
\text { is written as a contemporaneous account of events } \\
\text { drawing on her recollections and her husband's } \\
\text { notebooks in which he recorded all the things she told } \\
\text { him or asked about through blinking her eyes (rather like } \\
\text { Jean-Paul Bauby). The discourse is constructed around } \\
\text { the journey of Sue's illness until her discharge home. Sue } \\
\text { is an engaging person, concerned about others, and gives } \\
\text { a balanced account of her experiences of compassionate } \\
\text { or uncompassionate care. If there is a bad incident, a } \\
\text { good one showing excellent compassionate caring is } \\
\text { described soon after. This gives a balance that is lacking } \\
\text { in The Diving Bell and the Butterfly. There is very little } \\
\text { that dates the story. }\end{array}$ \\
\hline $\begin{array}{l}\text { Bauby JD (1998) The Diving } \\
\text { Bell and the Butterfly, } \\
\text { London: Harper Collins } \\
\text { Publishers. } \\
\text { (nominated three times). Also } \\
\text { available as a film. }\end{array}$ & $\begin{array}{l}\text { Jean-Dominique Bauby was the well-known editor of } \\
\text { Elle magazine who was left in a locked in state following } \\
\text { a stroke. His narrative is about his life as a person who is } \\
\text { hospitalised and dependent on others for everything and } \\
\text { only able to communicate by blinking his left eye. The } \\
\text { main discourse is loss of identity. There is also advocacy } \\
\text { shown by a speech therapist. It is a beautifully written } \\
\text { book and not a misery memoire even though the way he } \\
\text { treated is so often totally without any caring or } \\
\text { compassion. It shows the triumph of the human spirit } \\
\text { over adversity. It demonstrates that debilitated patients } \\
\text { need to be seen as human beings at all times. }\end{array}$ \\
\hline $\begin{array}{l}\text { Burnett FH (1905) A Little } \\
\text { Princess, Ware: Wordsworth } \\
\text { Children's Classics. } \\
\text { (available as free download } \\
\text { from Gutenberg.org) } \\
\text { Also available as a film. }\end{array}$ & $\begin{array}{l}\text { The main character is Sara who is at a boarding school in } \\
\text { the late } 1800 \text { s. When she is orphaned and her father's } \\
\text { fortune lost, she is used as a servant. The central } \\
\text { discourse is one of compassion for those less fortunate } \\
\text { than oneself. The thread of accident of fortune/birth runs } \\
\text { through the book and wealthy Sara recognises this and } \\
\text { subsequently is sustained in part by her acceptance of her } \\
\text { loss of good fortune rather than asking why bad things } \\
\text { should have happened to her. She continues to try to help } \\
\text { others less fortunate than herself even when she has } \\
\text { absolutely nothing to give other than a smile. }\end{array}$ \\
\hline $\begin{array}{l}\text { Carel H (2008) Illness (the } \\
\text { art of living) McGill-Queen's } \\
\text { University Press }\end{array}$ & $\begin{array}{l}\text { This book is written by Havi Carel, a philosophy lecturer, } \\
\text { young woman, terminally ill with a rare disease. She was } \\
\text { a fit young woman who suddenly found that she was } \\
\text { increasingly short of breath. Within minutes of diagnosis } \\
\text { her identity changed to one of being terminally ill with } \\
\text { less than ten years to live. She draws on her insights as a } \\
\text { philosopher to analyse her experiences, how she is }\end{array}$ \\
\hline
\end{tabular}




\begin{tabular}{|c|c|}
\hline & $\begin{array}{l}\text { treated and suggests a "phenomenology of illness" } \\
\text { should be developed to improve how healthcare } \\
\text { professionals behave. The book encourages readers to } \\
\text { about what we do, how we behave and how the systems } \\
\text { in place get in the way rather than allow individuals to } \\
\text { work with their problems and illnesses. }\end{array}$ \\
\hline $\begin{array}{l}\text { De Beauvoir S (1981) } \\
\text { Adieux: Farewell to Sartre, } \\
\text { London: Penguin Books }\end{array}$ & $\begin{array}{l}\text { This is a diary-based chronological account by the } \\
\text { feminist writer, Simone de Beauvoir of the last ten years } \\
\text { of her life with the French philosopher Jena-Paul Sartre } \\
\text { until his death. This holds the entire discourse together } \\
\text { by charting the ups and down and the impact of his } \\
\text { physical decline on Sartre. De Beauvoir expresses very } \\
\text { little of her own emotions and mainly approaches the } \\
\text { discourse with a certain disengagement and } \\
\text { objectiveness. The honest accounts such as Sartre leaving } \\
\text { urine stains on chairs engender compassion and would } \\
\text { help students understand the reality of physical decline } \\
\text { and what carers have to cope with. The names and } \\
\text { political debates of the time are a barrier at times. }\end{array}$ \\
\hline $\begin{array}{l}\text { Gibran K (1991) The } \\
\text { Prophet, London: Pan }\end{array}$ & $\begin{array}{l}\text { The people and places are fictional. The narrator is The } \\
\text { Prophet (Almustafa) who is recognised as a spiritual } \\
\text { leader, or philosopher, or wise man by the People of } \\
\text { Orphalese. His primary narrative is that he is a traveller, } \\
\text { a seeker of wisdom. He has been in Orphalese for twelve } \\
\text { years and is longing to return to his own homeland but } \\
\text { before he goes, he imparts his advice. If followed, } \\
\text { compassion will be demonstrated towards others as well } \\
\text { as towards oneself. }\end{array}$ \\
\hline $\begin{array}{l}\text { Lee H (1960) To Kill a } \\
\text { Mockingbird, Philadelphia, } \\
\text { USA; JD Lippincott \& Co. } \\
\text { Also available as a film. }\end{array}$ & $\begin{array}{l}\text { A key text used in many American schools to explore } \\
\text { racial divides and social inequality. The story is told from } \\
\text { the eyes of the six year old daughter of a white lawyer } \\
\text { who defends a black man unjustly accused and found } \\
\text { guilty of rape. Narratives include racial identities, } \\
\text { courage, compassion, and gender. The main topic is } \\
\text { accepting the differences in others. One discourse is the } \\
\text { coexistence of good and evil and another is the transition } \\
\text { from childhood innocence to the complex attitudes of } \\
\text { adults that include hatred and prejudice. }\end{array}$ \\
\hline $\begin{array}{l}\text { Montgomery LM (1908) } \\
\text { Anne of Green Gables, } \\
\text { Boston, USA: LC Page \& } \\
\text { Co. } \\
\text { Also available as a film and } \\
\text { adapted for the stage as a } \\
\text { musical. }\end{array}$ & $\begin{array}{l}\text { Set in Prince Edward Island, Canada, Anne Shirley, an } \\
\text { orphan with a very vivid imagination, is sent at age } 11 \text { to } \\
\text { Avonlea. A mistake had been made as they wanted a boy } \\
\text { to help on the farm. The discourse is structured around } \\
\text { Anne, who she is and who she becomes through the } \\
\text { guidance of her adopted family. The whole narrative is } \\
\text { one of caring, for each other, for the stranger or orphan, } \\
\text { for families in the community. The families help each } \\
\text { other and that sense of caring leads to the expression of } \\
\text { compassion in how Anne is treated and becomes valued. } \\
\text { The narrative suggests that the person who deserves } \\
\text { compassion should not to simply be a passive recipient }\end{array}$ \\
\hline
\end{tabular}




\begin{tabular}{|c|c|}
\hline & $\begin{array}{l}\text { but should adopt a positive mind set and to have } \\
\text { resilience. }\end{array}$ \\
\hline $\begin{array}{l}\text { Perry B (1998) Moments in } \\
\text { Time: Images of Exemplary } \\
\text { Nursing Care, Canadian } \\
\text { Nurses Association. }\end{array}$ & $\begin{array}{l}\text { The book in which this poem is presented at the end as a } \\
\text { distillation of the preceding chapters was based on } \\
\text { Perry's doctoral thesis. Perry is a Canadian nurse who } \\
\text { observed exemplar nurses in practice. This is one of the } \\
\text { greatest strengths of this book because such a clear } \\
\text { articulation of the art and compassion of real, good } \\
\text { nurses is very hard to find. The book conveys numerous } \\
\text { examples of nurses being caring and compassionate and } \\
\text { perhaps every nursing student should read the whole } \\
\text { book as it will provide them with a form of 'role } \\
\text { modelling' that some may struggle to witness in clinical } \\
\text { practice. This book holds the potential to make real the } \\
\text { ideas contained in the } 6 \text { C's. }\end{array}$ \\
\hline $\begin{array}{l}\text { Walker B (2010) Reading by } \\
\text { Moonlight, Penguin } \\
\text { Australia. }\end{array}$ & $\begin{array}{l}\text { The author, a university lecturer who teaches writing and } \\
\text { had published other books before this one is writing } \\
\text { about being diagnosed with breast cancer and her } \\
\text { subsequent treatment through surgery, chemotherapy, } \\
\text { radiotherapy, reconstruction and survival. The story } \\
\text { conveys how the diagnosis ripped her from her former } \\
\text { identity of being a healthy single parent of a } 15 \text { year old } \\
\text { son to being a person who was ill with a life-threatening } \\
\text { disease, afraid that she might not live to raise her son to } \\
\text { adulthood. She writes that being caring and } \\
\text { compassionate can be "uphill work". }\end{array}$ \\
\hline \multicolumn{2}{|l|}{ Poems } \\
\hline $\begin{array}{l}\text { Brown, MF (2010) Morning } \\
\text { Song In: What on Earth. } \\
\text { Moon Pie Press }\end{array}$ & $\begin{array}{l}\text { The narrator, probably a woman, is in her kitchen starting } \\
\text { to get breakfast ready. She speaks of a woman (possibly } \\
\text { herself) grieving for a dead child. The rituals in her } \\
\text { actions demonstrate caring particularly through the acts } \\
\text { of feeding and nurturing others. Caring is shown also by } \\
\text { the spouse - his kiss on the crown of her head is a form } \\
\text { of blessing. Caring is portrayed as holy. There is } \\
\text { compassion for all things frail and imperilled. Discourses } \\
\text { include the importance of being aware of the present } \\
\text { moment (mindfulness), the importance of celebrating } \\
\text { those who are special to us and the need to make sense of } \\
\text { a great tragedy. }\end{array}$ \\
\hline $\begin{array}{l}\text { Clare J (1793 -1864) I am. In: } \\
\text { David Wright (ed) (1968) } \\
\text { The English Book of English } \\
\text { Romantic Verse, London: } \\
\text { Penguin Books, p272. }\end{array}$ & $\begin{array}{l}\text { The writer was in a psychiatric institution and the } \\
\text { identity conveyed is one of an old man, forgotten by } \\
\text { everyone, someone that was important in the past but is } \\
\text { no longer. There is a sense of longing for death and of } \\
\text { having been abandoned by family and friends (which } \\
\text { might be a mistaken belief due to the nature of his mental } \\
\text { illness). The over-arching narrative is one of lack of care } \\
\text { and compassion and a feeling of abandonment. This } \\
\text { poem can bring into awareness the lived experience of } \\
\text { mental illness to demonstrate the vivid nature of how } \\
\text { feeling depressed and lonely can be for an individual. }\end{array}$ \\
\hline
\end{tabular}




\begin{tabular}{|c|c|}
\hline & $\begin{array}{l}\text { The rhythm of the lines could seem to mirror breathing } \\
\text { on a ventilator. }\end{array}$ \\
\hline $\begin{array}{l}\text { Davis C (2006) The Nurse's } \\
\text { Pockets. In: Judy Schaefer } \\
\text { (ed) The Poetry of Nursing, } \\
\text { Ohio, Kent State University } \\
\text { Press. }\end{array}$ & $\begin{array}{l}\text { This poem is about a nurse who cares for dying patients } \\
\text { and has to do last offices, clear away everything and } \\
\text { prepare the bed when they die. Views were mixed on this } \\
\text { poem as to whether it shows how privileged nurses are to } \\
\text { be involved in caring for a dying patient and they should } \\
\text { respond appropriately or whether it is over- } \\
\text { sentimentalised. }\end{array}$ \\
\hline $\begin{array}{l}\text { Finn, Charles C (1966) } \\
\text { Please hear what I'm not } \\
\text { saying, USA (self-published) }\end{array}$ & $\begin{array}{l}\text { The poem relates how the real person is hidden behind "a } \\
\text { thousand masks" and is in a "self-built" prison of } \\
\text { "confusion", "fear" and "aloneness". There is a sense too } \\
\text { that the person does not know who she or he really is - } \\
\text { that the true person is waiting to be created and that this } \\
\text { can only happen when someone sees through the mask } \\
\text { with acceptance and love. The primary discourse is of the } \\
\text { dissonance between our presenting identities and our } \\
\text { hidden identities and of the desire to be valued. The } \\
\text { poem can help people recognise that patients may be } \\
\text { hiding their suffering behind a mask so it is important to } \\
\text { be able to recognise this and respond in a caring and } \\
\text { compassionate way. }\end{array}$ \\
\hline $\begin{array}{l}\text { Hogben, L (c1970) The } \\
\text { Nurse's Reply (to Look } \\
\text { Closer Nurse by } \\
\text { McCormack) }\end{array}$ & $\begin{array}{l}\text { This poem was written in response to McCormack's } \\
\text { Crabbit Old Woman (see below). It sets out how busy the } \\
\text { nurse is, how there is too much to do. In many ways, it } \\
\text { perhaps misses the point of the original poem and can be } \\
\text { interpreted as trying to give an excuse for not seeming } \\
\text { more caring and compassionate }\end{array}$ \\
\hline $\begin{array}{l}\text { Kipling R (1895, 2009) If, In: } \\
\text { Rewards and Fairies, Project } \\
\text { Gutenberg ebook }\end{array}$ & $\begin{array}{l}\text { This poem was written by a Victorian author famous for } \\
\text { his excellent story-telling and fables. Kipling himself was } \\
\text { in great need of care and compassion through his } \\
\text { childhood having been cruelly treated by adults charged } \\
\text { with his care and he lost both his sons in WW } 1 \text {. The } \\
\text { poem is constructed rather like a set of rules so it could } \\
\text { possibly be used in comparison to the rules of conduct set } \\
\text { for nurse. It is frequently read at funerals. }\end{array}$ \\
\hline $\begin{array}{l}\text { McCormack P (1966) } \\
\text { Crabbit Old Woman (also } \\
\text { called Look Closer Nurse or } \\
\text { Kate) Sunnyside Hospital } \\
\text { Montrose Newsletter } \\
\text { (nominated three times). }\end{array}$ & $\begin{array}{l}\text { This poem, often mistakenly believed to be a genuine } \\
\text { poem written by an old lady on a ward, was actually } \\
\text { written by a nurse. The old woman who is "writing" the } \\
\text { poem reveals the multiple identities which she has held } \\
\text { as a child with parents and siblings, a teenager dreaming } \\
\text { of love, a young bride, a mother, a grandmother, a widow } \\
\text { and now a patient in a hospital or resident in a care home. } \\
\text { She feels that she is invisible to the nurse(s) caring for } \\
\text { her. It implies the nurse lacks a holistic approach and } \\
\text { does not 'know' the patient consequently there is a lack } \\
\text { of compassion and nursing seems to be simply task- } \\
\text { orientated role. }\end{array}$ \\
\hline $\begin{array}{l}\text { Nolte DL (1954, @1972) } \\
\text { Children learn what they live, }\end{array}$ & $\begin{array}{l}\text { This poem is a list of phrases claiming that the } \\
\text { environment in which a child grows up in will affect their }\end{array}$ \\
\hline
\end{tabular}




\begin{tabular}{|c|c|}
\hline $\begin{array}{l}\text { The Torrence Herald, Los } \\
\text { Angeles, USA. }\end{array}$ & $\begin{array}{l}\text { character and in a very direct fashion. The narrative is } \\
\text { that the child's development of character is affected by } \\
\text { the environment in which they are raised. The poem is a } \\
\text { subtle discourse on caring and compassion with a central } \\
\text { theme that good begets good and evil begets evil. }\end{array}$ \\
\hline $\begin{array}{l}\text { Perry B (1998) As you } \\
\text { journey through life. In: Beth } \\
\text { Perry (1998) Moments in } \\
\text { Time: Images of Exemplary } \\
\text { Nursing Care, Canadian } \\
\text { Nurses Association at } \\
\text { pp.157-158 }\end{array}$ & $\begin{array}{l}\text { This poem was nominated separately from the book in } \\
\text { which it appears. In the poem, the narrator's identity is } \\
\text { that of an exemplary nurse telling others what they need } \\
\text { to do, how they need to be as people, in order to become } \\
\text { exemplary nurses themselves. The narrative is presented } \\
\text { as a string of instructions to help people (nurses) on their } \\
\text { journey through life. It is the journey that holds all the } \\
\text { threads together about how to care for others and how to } \\
\text { care for oneself, the importance of compassion (implied } \\
\text { as a concept, not specifically named) and the importance } \\
\text { of becoming the best person you possibly can be whilst } \\
\text { recognising that perfection is impossible. }\end{array}$ \\
\hline $\begin{array}{l}\text { Taylor, A. (2012) 'Kindness', } \\
\text { In: And Time Stood Still, } \\
\text { Dublin: Brandon Press, } \\
\text { p.189. }\end{array}$ & $\begin{array}{l}\text { Alice Taylor is an Irishwoman who has authored many } \\
\text { books celebrating and narrating instances of rural life in } \\
\text { Ireland. Her book reminisces about her family and } \\
\text { friends who have died. It can be seen as a therapeutic } \\
\text { book that deals with compassion. The poem "Kindness" } \\
\text { is a thank you poem to someone who cared in a } \\
\text { meaningful way for the author in a time of immense pain, } \\
\text { thereby enabling her 'frozen being' to come to life again. } \\
\text { The poem provides a simple description of how small } \\
\text { gestures (through presence and action) can have } \\
\text { resounding effects on a person's suffering. It } \\
\text { demonstrates that providing compassionate care can be } \\
\text { as simple as being warm in presence and demeanour and } \\
\text { offering "a caring hand". }\end{array}$ \\
\hline \multicolumn{2}{|r|}{ 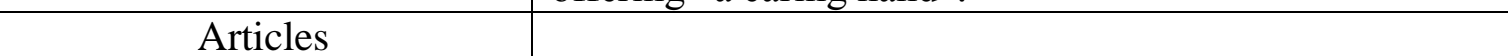 } \\
\hline $\begin{array}{l}\text { Doyal L, Papanni S, and } \\
\text { Anderson J. (2008) 'Elvis } \\
\text { died and I was born': Black } \\
\text { African men negotiating } \\
\text { same sex desire in London, } \\
\text { Sexualities, 11, pp.171-192. }\end{array}$ & $\begin{array}{l}\text { This article explores accounts given by gay black men. It } \\
\text { raises the issue of discrimination and stigma against a } \\
\text { marginalized group. The overall discourse is one of the } \\
\text { difficulty of constructing a comfortable, empowering } \\
\text { identify for oneself as a Black African man who has sex } \\
\text { with other men. There is a small sense of triumph over } \\
\text { tragedy - the participants are able to lead lives that are } \\
\text { more truthful to themselves than they were able to in the } \\
\text { past even though they are not yet able to be fully open. } \\
\text { The narrative is characterised by the primarily negative } \\
\text { experiences and lack of compassion or understanding } \\
\text { shown by those (family and church) who should be } \\
\text { closest to these men. }\end{array}$ \\
\hline $\begin{array}{l}\text { Quill TE, Cassell C (1995) } \\
\text { Nonabandonment: a central } \\
\text { obligation for physicians, } \\
\text { Annals of Internal Medicine, } \\
\text { 125(5), pp368-373 }\end{array}$ & $\begin{array}{l}\text { This is a reflective account of how a doctor learnt the } \\
\text { importance of getting to know his patients (in the article } \\
\text { there are two female patients discussed) so that a } \\
\text { relationship can be built allowing the doctor and patient } \\
\text { to work together. The concept of non-abandonment is }\end{array}$ \\
\hline
\end{tabular}




\begin{tabular}{|c|c|}
\hline & $\begin{array}{l}\text { introduced with analysis of the ethical framework that } \\
\text { underpins it however, some of this now reads as rather } \\
\text { dated although it was new at the time. }\end{array}$ \\
\hline \multicolumn{2}{|l|}{ Films } \\
\hline $\begin{array}{l}\text { Apollo } 13 \text { (1995) Director } \\
\text { Ron Howard, starring Tom } \\
\text { Hanks }\end{array}$ & $\begin{array}{l}\text { Based on the real life events as NASA tried to bring the } \\
\text { crew of the Apollo } 13 \text { space shuttle home safely. The } \\
\text { narrative is held together by how the three men's lives } \\
\text { were saved against the odds by a combination of } \\
\text { engineering problem-solving excellence from a variety of } \\
\text { different teams, teamwork and leadership. A global } \\
\text { public kept vigil in a way that was probably unknown at } \\
\text { the time. The way the plight of the astronauts engaged } \\
\text { the public has been mirrored in responses to other } \\
\text { situations. Often it seems easier for the public to engage } \\
\text { when they can put a face, a name and an identity to the } \\
\text { person in peril. There are so many demands upon our } \\
\text { compassion these days with global news that the public is } \\
\text { at risk of 'compassion fatigue'. }\end{array}$ \\
\hline $\begin{array}{l}\text { Dad (1989) Director Gary } \\
\text { David Goldberg, starring } \\
\text { Ted Danson, Jack Lemmon } \\
\text { and Ethan Hawke. }\end{array}$ & $\begin{array}{l}\text { This film focuses on "Dad", Jake Tremont, a man in his } \\
\text { seventies whose wife has a heart attack so John, their son } \\
\text { (played by Ted Danson) is called from his busy Wall } \\
\text { Street life to help. Dad appears to have dementia and at } \\
\text { one point is hospitalised having gone catatonic on being } \\
\text { told he has cancer. There are scenes where the healthcare } \\
\text { professionals are uncaring resulting in a tearjerker when } \\
\text { John takes his father home. Eventually it is revealed that } \\
\text { Dad does not have dementia but has a form of } \\
\text { depression, in part because of the controlling behaviour } \\
\text { of his wife. Relationships between the different family } \\
\text { members heal as the film progresses. There is } \\
\text { forgiveness and acceptance. The film evokes laughter } \\
\text { and tears and conveys a sense of how caring for someone } \\
\text { can bring joy. It shows that compassionate caring is } \\
\text { about going the extra mile. }\end{array}$ \\
\hline $\begin{array}{l}\text { Defiance (2008) Producer } \\
\text { and Director Edward Zwick, } \\
\text { starring Daniel Craig. }\end{array}$ & $\begin{array}{l}\text { Based on real life event, the film centres around a Jewish } \\
\text { family, the Bielskis, living in Poland during the Second } \\
\text { World War. There are suggestions in the film that they } \\
\text { were smugglers although sanitised versions on the } \\
\text { internet suggest they were millers and grocers. When } \\
\text { German soldiers invade their village and kill people, } \\
\text { Tuvia (Daniel Craig) hides in the forest eventually being } \\
\text { joined by many more people. There are violent clashes } \\
\text { and disagreements at times between the Bielski brothers } \\
\text { and although compassion is evident, at times it is } \\
\text { constrained by the surrounding circumstances. }\end{array}$ \\
\hline $\begin{array}{l}\text { Dr Peter Living with AIDS } \\
\text { Documentary, Dr Peter AIDS } \\
\text { Foundation, Canada }\end{array}$ & $\begin{array}{l}\text { This is a compilation of the weekly films that tracked a } \\
\text { young Canada doctor from his diagnosis with AIDS at a } \\
\text { time when there was no effective treatment and huge } \\
\text { stigma regarding the illness and homosexuality. Dr Peter } \\
\text { talks about facing adversity, dealing with the attitudes of }\end{array}$ \\
\hline
\end{tabular}




\begin{tabular}{|c|c|}
\hline & $\begin{array}{l}\text { others, and acceptance of death whilst finding joy in the } \\
\text { moment and meaning in suffering. The approach of this } \\
\text { patient, one of grace under pressure and acceptance of } \\
\text { loss without rancour or self-pity shines throughout. }\end{array}$ \\
\hline $\begin{array}{l}\text { Invictus (2009) Director Clint } \\
\text { Eastword, starring Morgan } \\
\text { Freeman as Nelson Mandela }\end{array}$ & $\begin{array}{l}\text { The film is set in the immediate aftermath of the end of } \\
\text { apartheid in South Africa. Nelson Mandela, who has } \\
\text { spent decades in prison, has been elected as President. } \\
\text { He is determined to unify a very divided country rather } \\
\text { than seek revenge for what he has experienced. The } \\
\text { Rugby World Cup competition is due to occur and } \\
\text { traditionally black South Africans had always supported } \\
\text { whoever was playing against the Springboks (the white } \\
\text { South African national team). Mandela sees this as a } \\
\text { tool to unite the country behind the Springboks. } \\
\text { Mandela also demonstrates the importance of making } \\
\text { everyone, no matter who they are, feel visible and } \\
\text { important to him. Nelson Mandela has secured his place } \\
\text { in history as a person of stature, forgiveness and } \\
\text { compassion. }\end{array}$ \\
\hline $\begin{array}{l}\text { Iris (2001) Director } \\
\text { Richard Eyre, starring Judy } \\
\text { Dench, Jim Broadbent and } \\
\text { Kate Winslet. }\end{array}$ & $\begin{array}{l}\text { The narrative is based on the true life account of Iris } \\
\text { Murdoch, as written by her husband John, so is strongly } \\
\text { biographical. The film shows a brilliant mind being } \\
\text { eroded and destroyed by dementia. The chronology of } \\
\text { her decline is interspersed with flashbacks to earlier } \\
\text { times. It is Iris herself, superbly portrayed by Dame Judi } \\
\text { Dench, who holds the narrative of care and compassion } \\
\text { (or lack of compassionate caring at times) together. The } \\
\text { rarified atmosphere of Oxford academia and advanced } \\
\text { philosophy contrasts with the challenges regarding caring } \\
\text { for someone with Alzheimer's. The film is also a story of } \\
\text { love and aging. }\end{array}$ \\
\hline $\begin{array}{l}\text { Mash (1970) Director Robert } \\
\text { Altman }\end{array}$ & $\begin{array}{l}\text { A film based on the 4077th Mobile Army Surgical } \\
\text { Hospital (later a television series) and set in Korea during } \\
\text { the Korean War (1950-1953). It shows life and death } \\
\text { issues coupled with the black humour and portrays the } \\
\text { frenetic activity of a MASH and the horrors and futility } \\
\text { of their role. It also demonstrates coping strategies such } \\
\text { as humour and resilience. Some clips could be used such } \\
\text { as the one where Hawkeye takes the time to speak } \\
\text { reassuringly to a patient with a neck wound. Students } \\
\text { could be asked to comment on what they saw and } \\
\text { through that they could identify the importance of seeing } \\
\text { the human being, not merely the injury and how it is } \\
\text { possible to do this whilst still giving instructions to the } \\
\text { team in a calm manner. There is a fluid professionalism } \\
\text { in how the care is portrayed, coupled with compassion. }\end{array}$ \\
\hline $\begin{array}{l}\text { Mission to Lars (2012) Stars } \\
\text { Kate, Will and Tom Spicer } \\
\text { (siblings) }\end{array}$ & $\begin{array}{l}\text { A real life film. Tom has Fragile X syndrome and lives in } \\
\text { a residential home. He is a huge fan of Ulrich Lars from } \\
\text { the band Metallica. His siblings (Kate a journalist and } \\
\text { Will a film-maker) decide to take him to America to }\end{array}$ \\
\hline
\end{tabular}




\begin{tabular}{|c|c|}
\hline & $\begin{array}{l}\text { watch Metallica and to meet Lars and make a film in the } \\
\text { process which has helped raise money for the charity } \\
\text { Mencap (for people with learning difficulties). The } \\
\text { viewer feels compassion towards the siblings who started } \\
\text { off meaning well but start to drown under the challenges } \\
\text { and for Tom, whose life is one continual challenge } \\
\text { because of his syndrome. At times, Will and Kate lack } \\
\text { the skills to cope with Tom's needs and sometimes lack } \\
\text { compassion (mainly shown as Kate's failure as Will is } \\
\text { behind the camera). Lars Ulrich seems to ooze and } \\
\text { exemplify compassion. }\end{array}$ \\
\hline $\begin{array}{l}\text { One flew over the cuckoo's } \\
\text { nest (1975) (based on } 1962 \\
\text { book by Ken Kersey) } \\
\text { Directed by Milos Forman. } \\
\text { Starring Jack Nicholson as } \\
\text { Murphy. }\end{array}$ & $\begin{array}{l}\text { Murphy was imprisoned for the statutory rape of a } 15 \\
\text { year old. In prison he got into fights and was lazy on } \\
\text { work details so he was sent to the psychiatric hospital for } \\
\text { evaluation. He befriends the Chief, a very tall, solid } \\
\text { looking native American who is said to be "deaf and } \\
\text { dumb". Murphy continues to be manipulative and } \\
\text { challenges the nurses' and doctors' authority. A contrast } \\
\text { emerges whereby the people whose professional role is to } \\
\text { care, are less caring or compassionate than either Murphy } \\
\text { or the Chief. Despite mental illness, these were still } \\
\text { people and that they should be treated with care and } \\
\text { compassion. A strong discourse is that despite mental } \\
\text { illness, people should be treated with care and } \\
\text { compassion. Eventually, post-frontal lobotomy when } \\
\text { Murphy's essential identity has been destroyed, the Chief } \\
\text { kills him then escapes. The killing is intended to be seen } \\
\text { as a compassionate response. }\end{array}$ \\
\hline $\begin{array}{l}\text { On Giant's Shoulders (1979) } \\
\text { A BBC 'Play of the Week' } \\
\text { drama production. Director } \\
\text { Anthony Simmons. Starring } \\
\text { Terry Wiles (as himself), Judi } \\
\text { Dench and Bryan Pringle as } \\
\text { his adoptive parents. Also } \\
\text { available as a book by } \\
\text { Marjorie Wallace and } \\
\text { Michael Robson. }\end{array}$ & $\begin{array}{l}\text { Based on real life, the film follows the early life of Terry } \\
\text { Wiles who was born without arms or legs as a result of } \\
\text { his mother taking thalidomide during pregnancy. He was } \\
\text { eventually adopted by a childless middle-aged couple } \\
\text { and taught to live as independent a life as possible. } \\
\text { Hazel, the adoptive mother, was initially lacking in } \\
\text { compassion and in fact had had two children removed as } \\
\text { she was deemed an 'unfit' mother but she learnt to be } \\
\text { compassionate. Len, the adoptive father, has compassion } \\
\text { but sometimes that was directed into practical and } \\
\text { sometimes unsuccessful attempts to manufacture } \\
\text { something to help Terry overcome his disabilities. For all } \\
\text { of them, the main discourse is one of swimming against } \\
\text { the tide, of life being a constant struggle that you only } \\
\text { survive if you have help from 'ordinary' people rather } \\
\text { than professionals or the state. The film implies that } \\
\text { being a professional carer (doctor, nurse, teacher, social } \\
\text { worker) can be a barrier to being caring or } \\
\text { compassionate. It indicates that care needs to be centred } \\
\text { on the individual and a caring, compassionate response } \\
\text { might be impossible in the face of limited resources } \\
\text { (personal, organisational and maybe professional). }\end{array}$ \\
\hline
\end{tabular}




\begin{tabular}{|c|c|}
\hline $\begin{array}{l}\text { Patch Adams (1998) Director } \\
\text { Tom Shadyak starring Robin } \\
\text { Williams }\end{array}$ & $\begin{array}{l}\text { Based on a true story, Patch got his nickname from } \\
\text { another patient, Arthur, in the psychiatric hospital that he } \\
\text { had checked himself into, who taught him to see the } \\
\text { person, not just the problem, and provide practical help. } \\
\text { Patch uses (misuses at times in the film) humour to help } \\
\text { patients feel better as he believes that medicine lacks } \\
\text { compassion and needs to be humanised. The film charts } \\
\text { Patch's challenges to qualify as a doctor, some of the } \\
\text { mistakes he made and his dream of setting up a new type } \\
\text { of hospital. The discourse reveals that listening to } \\
\text { patients, seeing them as real people not just diseases and } \\
\text { problems to be fixed is important. Also, caring requires } \\
\text { seeing the real person, not an idealised version of that } \\
\text { person, so that caring can be carried out in a way that is } \\
\text { safe for the patient and the person delivering care. } \\
\text { Compassion for another has to be balanced with care for } \\
\text { oneself. The over-the-top craziness of Robin Williams } \\
\text { makes it hard to engage with. }\end{array}$ \\
\hline $\begin{array}{l}\text { The English Patient (1996) } \\
\text { Director Anthony Minghella, } \\
\text { starring Ralph Fiennes and } \\
\text { Kristen Scott Thomas }\end{array}$ & $\begin{array}{l}\text { The main character is a Hungarian, Count Lazlo Almasy, } \\
\text { who is an archaeologist/pilot and also a spy during the } \\
\text { Second World War. He is shot down in the Egyptian } \\
\text { desert, cannot recall who he is and is so badly burned no } \\
\text { one recognises him so believe him to be English. As } \\
\text { patients are being evacuated in the event of a German } \\
\text { advance, when it becomes impossible to move him, an } \\
\text { army nurse, Hana, stays with him. There is also another } \\
\text { person, David, who has been tortured. The main } \\
\text { discourse is of pain and suffering, as witnessed in the } \\
\text { image of the burned body of the count, the amputated } \\
\text { thumbs of David, and the emotional pain evident in Hana } \\
\text { as she struggles with the weariness of war. This suffering } \\
\text { is alleviated by care and compassion offered mainly by } \\
\text { Hana. The scenes where Hana attends to the patient could } \\
\text { be used to show her non- judgmental approach to his } \\
\text { care. These could also be used to demonstrate her } \\
\text { communication skills because she consistently treats him } \\
\text { as a person and explains everything to him even when he } \\
\text { cannot respond. This contrasts to Bauby's carers in The } \\
\text { Diving Bell and the Butterfly (see above). She also listens } \\
\text { to him and recognises that telling his story is important to } \\
\text { him. }\end{array}$ \\
\hline $\begin{array}{l}\text { The Raging Moon (1971) } \\
\text { Director Bryan Forbes, } \\
\text { starring Malcolm McDowell } \\
\text { and Nanette Newman. Based } \\
\text { on the } 1964 \text { book by Peter } \\
\text { Marshall. }\end{array}$ & $\begin{array}{l}\text { The story is based mainly in a residential home for } \\
\text { people with major physical but not mental deficits and } \\
\text { follows two young people falling in love. Barry was } \\
\text { football mad but is now paralysed and wheelchair } \\
\text { dependent and has only just arrived at the home. Jill had } \\
\text { polio as a young adult and has been in the home for } \\
\text { several years. The discourse of caring and compassion is } \\
\text { held together by following the journey of Bruce's sudden } \\
\text { onset of disability, his adjustment to the loss of the life }\end{array}$ \\
\hline
\end{tabular}




\begin{tabular}{|c|c|}
\hline & $\begin{array}{l}\text { that he had, his acceptance of the life he now has, to his } \\
\text { planning for the future with Jill. The sadness is that they } \\
\text { are not allowed this future as Jill dies. However, the } \\
\text { compassion shown by the other residents who have been } \\
\text { disabled much longer helps Bruce begin the grieving } \\
\text { process. There is a sense that compassion needs to be } \\
\text { accompanied by self-help and being prepared to keep } \\
\text { batting away at the challenges that life throws at you. } \\
\text { The film is rather dated but it is very moving. }\end{array}$ \\
\hline $\begin{array}{l}\text { Wit (2001) Director Mike } \\
\text { Nichols, starring Emma } \\
\text { Thompson as Vivien. Also } \\
\text { available as a play. }\end{array}$ & $\begin{array}{l}\text { Vivien Bearing is a professor, renounced scholar and } \\
\text { John Donne expert (one of whose poems runs as a thread } \\
\text { through the film). She has been diagnosed with stage } 4 \\
\text { ovarian cancer and agrees to enter a research trial. The } \\
\text { film follows the chemotherapy, her sickness, physical } \\
\text { decline and contrasts the doctor who wants her to } \\
\text { complete the full set of chemotherapy for his research } \\
\text { study with the nurse who provides care and compassion } \\
\text { when Vivien is eventually open to receiving this. The } \\
\text { discourse shows that caring means seeing the real person, } \\
\text { not just the presented person. Vivien, as the real human } \\
\text { being, is invisible to the doctors even though they would } \\
\text { clearly deny this. Compassion is the active expression of } \\
\text { that deep caring and is seen in facial expressions, touch, } \\
\text { and human connection. It is being wholly present, in the } \\
\text { moment, with the patient. }\end{array}$ \\
\hline $\begin{array}{l}\text { X-Files - episode called "All } \\
\text { Things" Director Gillian } \\
\text { Anderson. }\end{array}$ & $\begin{array}{l}\text { This is an episode of a popular science fiction series } \\
\text { where Mulder (David Duchovny) and Scully (Gillian } \\
\text { Anderson) are working on paranormal cases for the FBI. } \\
\text { This episode conveys themes of altered sex/gender roles, } \\
\text { Buddhism and eastern methodology v. western positivist } \\
\text { medical science and how we need to be mindful of this. } \\
\text { One of the discourses is how the man (Mulder) is the } \\
\text { emotional type and the woman (Scully) is presented as } \\
\text { the rationale type. Tolerance towards others and their } \\
\text { belief systems and experience of the world around them } \\
\text { form other discourses. }\end{array}$ \\
\hline \multicolumn{2}{|l|}{ Plays } \\
\hline $\begin{array}{l}\text { Les Miserables (Musical: } \\
1980 \text { in Paris, } 1985 \text { in } \\
\text { London) Also a } 2012 \text { film } \\
\text { produced by Working Farm } \\
\text { Films and } 1862 \text { book by } \\
\text { Victor Hugo) }\end{array}$ & $\begin{array}{l}\text { Jean Valjean is Prisoner } 24601 \text { who was excessively } \\
\text { harshly punished for stealing bread as a child to feed his } \\
\text { starving sister. Twenty years after his release, but still a } \\
\text { fugitive for failing to report to the police, Valjean has } \\
\text { become wealthy and has an adopted daughter. A police } \\
\text { officer, Javert, recognises him and knows that he is a } \\
\text { wanted fugitive. The film is set during the French } \\
\text { Revolution. The discourse is one of mercy allowing for } \\
\text { redemption and the fragility of the human condition - } \\
\text { how harsh circumstances and the primal instinct to } \\
\text { survive can drive out compassion. There is also a } \\
\text { discourse that relates to duty and how a rigid } \\
\text { interpretation of one's duty can prevent mercy or }\end{array}$ \\
\hline
\end{tabular}




\begin{tabular}{|l|l|}
\hline Oleanna, by David Mamet & $\begin{array}{l}\text { compassion being shown. Javert finally commits suicide } \\
\text { as he feels he has failed in his duty by failing to capture } \\
\text { or kill Valjean even though he had earlier been shown } \\
\text { mercy by Valjean. }\end{array}$ \\
\hline $\begin{array}{l}\text { This play focuses on John, a lecturer in an American } \\
\text { university seeking tenure and a female student Carol } \\
\text { (from a non-specified disadvantaged minority } \\
\text { background). The main discourse focuses on power } \\
\text { imbalances between lecturer and student, between } \\
\text { educated middle class and aspiring disadvantaged } \\
\text { groups, between male and female. There seems to be no } \\
\text { compassion in either character. Regarding concepts of } \\
\text { caring and compassion, the message (delivered } \\
\text { negatively) is that caring involves understanding - } \\
\text { understanding the needs of the other, the perspectives of } \\
\text { the other, understanding oneself, understanding how we } \\
\text { impact on others or how we might be perceived to } \\
\text { impact. }\end{array}$ \\
\hline
\end{tabular}


Table 2: $\quad$ Absence of compassion is characterised by:

\begin{tabular}{|l|l|}
\hline Absence of compassion is characterised by: & $\begin{array}{l}\text { Number of narratives containing } \\
\text { this characteristic }\end{array}$ \\
\hline Invisibilisation & 25 \\
\hline Abandonment & 24 \\
\hline $\begin{array}{l}\text { Offering only physical care not psycho-social- } \\
\text { emotional care }\end{array}$ & 15 \\
\hline Thoughtlessness (and insensitivity) & 12 \\
\hline Unkindness & 10 \\
\hline Disengagement / indifference & 9 \\
\hline Marginalisation & 8 \\
\hline Violence (actual or threatened) & 8 \\
\hline Treating the suffering person as a burden & 7 \\
\hline Injustice & 6 \\
\hline Prejudice & 6 \\
\hline Ignorance & 6 \\
\hline Failure to respect the dignity of the other person & 6 \\
\hline Intolerance & 5 \\
\hline Impatience & 5 \\
\hline Not offering hope & 5 \\
\hline Resentment & 5 \\
\hline Abruptness & 5 \\
\hline Loss of freedom & 5 \\
\hline Blame & 4 \\
\hline Distrust & 4 \\
\hline Using the other person as a means to an end & 4 \\
\hline Loneliness & 4 \\
\hline Roughness & 4 \\
\hline Unfriendliness & 4 \\
\hline Betrayal & 4 \\
\hline Dishonesty & 3 \\
\hline Denial of care & 3 \\
\hline Bullying & 3 \\
\hline Sullenness & 2 \\
\hline Denial of the truth & 2 \\
\hline Deviousness & 1 \\
\hline & \\
\hline
\end{tabular}


Table 3: $\quad$ Educating for Care and Caring

\begin{tabular}{|c|c|}
\hline $\begin{array}{l}\text { Practical expressions of Care and Caring are } \\
\text { characterised by: }\end{array}$ & $\begin{array}{l}\text { Number of narratives raising } \\
\text { this perspective }\end{array}$ \\
\hline $\begin{array}{l}\text { Compassionate caring means seeing the other person } \\
\text { and their suffering }\end{array}$ & 25 \\
\hline $\begin{array}{l}\text { Compassionate people do not abandon suffering } \\
\text { human beings }\end{array}$ & 24 \\
\hline Care can be divided into practical action and emotion & 18 \\
\hline $\begin{array}{l}\text { Being able to connect with the other person is } \\
\text { necessary to give good care }\end{array}$ & 17 \\
\hline $\begin{array}{l}\text { Compassion leads to caring leads to the practical } \\
\text { action of delivering care }\end{array}$ & 15 \\
\hline Care can simply be duty & 12 \\
\hline $\begin{array}{l}\text { The nature of an activity of care can be transformed } \\
\text { into caring through the engagement of compassion }\end{array}$ & 12 \\
\hline Caring as an emotion is characterised by compassion & 12 \\
\hline Caring can 'free' the person experiencing that care & 10 \\
\hline Caring can place a heavy burden on the carer & 10 \\
\hline Caring and compassion are not role restricted & 9 \\
\hline 'Ordinary' actions can covey care and compassion & 9 \\
\hline People can learn to be more caring and compassionate & 8 \\
\hline The delivery of care may be triggered by compassion & 8 \\
\hline $\begin{array}{l}\text { The delivery of care may be triggered by duty in the } \\
\text { absence of any sense of compassion or love }\end{array}$ & 7 \\
\hline Nurturing of others is a component of caring & 7 \\
\hline $\begin{array}{l}\text { Balance is needed not to give so much of oneself that } \\
\text { it is damaging }\end{array}$ & 7 \\
\hline $\begin{array}{l}\text { Professional distance does not mean compassion is or } \\
\text { has to be absent }\end{array}$ & 6 \\
\hline $\begin{array}{l}\text { Caring people should (have a duty to?) see the 'inner' } \\
\text { person }\end{array}$ & 5 \\
\hline Seeing caring as a privilege not a duty & 4 \\
\hline $\begin{array}{l}\text { Over-involvement in the lives of others is not } \\
\text { necessarily professional, caring or compassionate }\end{array}$ & 3 \\
\hline $\begin{array}{l}\text { Being caring and compassionate requires acceptance } \\
\text { of the other as they are even if they are not a 'good' } \\
\text { person since acceptance does not have to mean } \\
\text { approval }\end{array}$ & 2 \\
\hline $\begin{array}{l}\text { Caring involves understanding the needs and } \\
\text { perspectives of the other and self-understanding } \\
\text { (including how we might impact on others or be } \\
\text { perceived by others) }\end{array}$ & 2 \\
\hline
\end{tabular}


Box 1: The questionnaire

Q1 What is the one item (book, article, poem, play or film) that has had the most impact upon you as a caring, compassionate practitioner?

Q2. Why has this book, article, poem, play or film been so influential on you?

Q3. Which particular scene or section exemplifies to you what it means to be caring and compassionate?

Q4. How do you use your chosen item in your teaching and how do students respond?

Q5. Why would you recommend it to other health and social care professionals?

Q6. What is your professional title and/or qualification?

Q7. How long have you been qualified as a health or social care professional?

Q8. Which country did you train in?

Q9. Which country are you employed in at the moment? 
- Published narratives develop compassion

- Compassion means seeing your patients

- Compassion means being present

- Compassion means not abandoning 